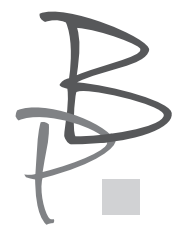

\author{
Sabina Kowalczyk* \\ Uniwersytet Warmińsko-Mazurski w Olsztynie \\ https://orcid.org/0000-0002-9641-3429
}

\title{
Magiczne i lecznicze właściwości pokrzyku na podstawie staropolskich zielników
}

\author{
Magical and curative properties of nightshade based \\ on Old Polish herbariums
}

\begin{abstract}
The aim of the article is to analyse how nightshade was described as a curative herb as well as the polish mandrake's equivalent. Research based on Old Polish herbariums written by Stefan Falimirz, Marcin from Urzędów and Szymon Syreński. In this article the issue of etymology of the polish name for Atropa belladonna (in polish: pokrzyk - krzyk [scream], krzak [bush]) was also important as well as the level of medical knowledge in 16th and 17th centuries. The author also compared nightshade to mandrake: their properties (psychedelic, curative), morphologic qualities and beliefs connected to anthropoid shape of root, supposed deadly scream of plant pulled from the ground and the use of this herb in magic.
\end{abstract}

Keywords: herbarium, 16th and 17th centuries, mandrake, nightshade.

\footnotetext{
* Sabina Kowalczyk - mgr, absolwentka filologii polskiej (spec. nauczanie języka polskiego i wiedzy o kulturze oraz edytorstwo tekstów) na Uniwersytecie Warmińsko-Mazurskim w Olsztynie. Doktorantka. Autorka rozprawy: Glos Syreniusza w sprawie wykorzystywania roślin w magii (,Meluzyna” 1/2020).
} 
Rośliny halucynogenne we wszystkich kulturach wiązano ze sferą sacrum ${ }^{1}$. Nie inaczej było w Polsce. Szczególnym kultem otaczano w naszym kraju między innymi mak biały, konopie, bielunia kędzierzawę czy pokrzyk wilczą jagodę². Ten ostatni utożsamiano z jednym z najbardziej legendarnych ziół - mandragorą lekarską.

Mandragora (Mandragora officinarum) występuje w krajach śródziemnomorskich, a także na obszarach Himalajów i Turkmenii. Dawniej wykorzystywana była często w praktykach magicznych. Oryginalnie ukształtowany korzeń, przywodzący na myśl ludzką sylwetkę, nazywany był alrunikiem/alrauną i odgrywał rolę amuletu³ ${ }^{3}$ Wyrywany z ziemi miał przeraźliwie krzyczeć, co mogło doprowadzić ludzi do obłędu lub śmierci. Wierzono, że dzięki tej roślinie można odzyskać utracone zdrowie, odnaleźć skarby, otworzyć każde drzwi. Traktowano ją również jako afrodyzjak ${ }^{4}$. W Polsce w stanie dzikim mandragora nie występowała, trudno ją też było uprawiać. Jednocześnie na tyle pobudzała wyobraźnię, że odczuwano potrzebę odnalezienia jej zamienników. Jednym z nich był pokrzyk, czyli Atropa belladonna ${ }^{6}$, choć cechy morfologiczne zaprzeczają podobieństwu roślin:

\begin{tabular}{|l|l|l|}
\hline Cechy & Mandragora officinarum & Atropa belladonna \\
\hline Wysokość & Do $30 \mathrm{~cm}$ & Do $2 \mathrm{~m}$ \\
\hline Kwiaty & $\begin{array}{l}\text { Duże, karbowanoząbkowane, } \\
\text { na długich szypułkach; } \\
\text { korona brudnobiała lub } \\
\text { zielonkawobiała }\end{array}$ & $\begin{array}{l}\text { Zwisłe, zwykle osadzone } \\
\text { pojedynczo w kątach liści; } \\
\text { korona brunatnofioletowa, } \\
\text { wewnątrz brudnoźłtawa, } \\
\text { ciemniej zyłkowana }\end{array}$ \\
\hline Owoce & Źólte, okrągłe & Czarne, lśniące, okrągłe'. \\
\hline
\end{tabular}

1 A. Zemanek, B. Zemanek, Roślina i „sacrum” w historii cywilizacji, [w:] Geografia i sacrum, red. W. Domański, B. Skiba, t. 2, Kraków 2005, s. 471-477.

2 B. Kuźnicka, Znaczenie roślin halucynogennych w polskich tradycjach kulturowych: zarys problematyki, „Analecta. Studia i Materiały z Dziejów Nauki” 1992, nr 1/1, s. 113-116.

3 W. Kopaliński, Stownik symboli, Warszawa 2001, s. 219 [hasło: Mandragora].

4 P. Kowalski, Kultura magiczna. Omen, przesąd, znaczenie, Warszawa 2007, s. 304-307 [hasło: Mandragora].

5 Innym zamiennikiem mandragory w Polsce był np. lulek czarny (zob. A. Zemanek, B. Zemanek, dz. cyt., s. 477). 
Wywodzą się one jednakże z tej samej rodziny (psiankowatych). Ponadto ich korzenie i liście zawierają atropinę - alkaloid, wykorzystywany obecnie w leczeniu bradykardii oraz jako środek przeciwbólowy i poszerzający źrenice, dawniej służący do kojenia bólu i zapobiegania bezsenności. Spożycie każdego z ziół w większych dawkach pobudza ośrodkowy układ nerwowy, wywołuje halucynacje, przymusowe ruchy, zakłócenie świadomości. Już 0,05 g atropiny stanowi niebezpieczeństwo dla zdrowia i życia człowieka ${ }^{6}$.

Celem niniejszego artykułu jest przeanalizowanie sposobu ukazania pokrzyku jako zioła leczniczego, ale też polskiego zamiennika mandragory. Zbadanie opisów tej rośliny w pierwszych polskich zielnikach umożliwia w szczególności odtworzenie wyobrażeń związanych z magicznymi właściwościami ziela, stosunku autorów staropolskich dzieł do funkcjonujących wówczas przesądów oraz wiedzy medycznej wykorzystywanej w wiekach XVI i XVII. Analizie poddane zostały:

- O ziołach i mocy ich Stefana Falimirza ${ }^{7}$ (1534, Kraków, drukarnia Floriana Unglera);

- Herbarz polski, to jest o przyrodzeniu ziół i drzew rozmaitych Marcina z Urzędowa ${ }^{8}$ (1595, Kraków, Drukarnia Łazarzowa - Łazarz Andrysowicz);

- Zielnik herbarzem z łacińskiego zowiq. To jest opisanie własne imion, kształtu, przyrodzenia, skutków i mocy ziót wszelakich drzew, krzewin

6 D. Frohne, Leksykon roślin leczniczych (red. wyd. I polskiego A. Noculak-Palczewska), Wrocław 2010, s. 96 [hasło: Atropa belladonna L.].

7 Stefan Falimirz (?-1534) - brak szczegółowych danych o jego życiu. Dyskusyjna jest kwestia uznawania go za botanika czy lekarza (zob. J. Szostak, Farmakognozja, farmacja galenowa $i$ aptekarstwo $w$ renesansowych zielnikach polskich, Warszawa 2006, s. 29-30). Wiadomo, że był dworzaninem Jana Tęczyńskiego i żył na dworze tego wojewody w Kraśniku. Falimirz, zachęcony przez drukarza Floriana Unglera, dokonał przekładu, przeróbki i swobodnej kompilacji innych łacińskich tekstów o tematyce botanicznej (S. Brzozowski, Falimirz Stefan, [w:] Słownik biologów polskich, red. S. Feliksiak, Warszawa 1987, s. 161), O ziołach i mocy ich zainicjowało cykl zw. „Unglerowskimi ogrodami zdrowia” (zob. przyp. 11).

8 Marcin z Urzędowa (XV/XVI wiek-1573) - lekarz, botanik, profesor Akademii Krakowskiej. W Padwie wypromował się na doktora medycyny. Zdobył znaczny majątek dzięki służbie jako lekarz przyboczny J. Tarnowskiego. Po wielu perypetiach osiedlił się na stałe w Sandomierzu. Był cenionym lekarzem, posiadał własny ogród botaniczny (dziś dąży się do jego odtworzenia. Zob. A. Suchecka, Sandomierski ogród Marcina z Urzędowa, „Głos Ziemi Urzędowskiej” 2015, s. 81-90). To prawdopodobnie w Sandomierzu zaczą prace nad Herbarzem polskim, w którym starał się poprawić błędy poprzedników (szczególnie Falmirza) i dokonał rewizji źródeł (L. Hajdukiewicz, Marcin z Urzędowa, [w:] Internetowy Polski Słownik Biograficzny, https://www.ipsb. nina.gov.pl/a/biografia/marcin-z-urzedowa?print [stan z dn. 11.01.2019]). 
i korzenia ich, kwiatu, owoców, soków, miazg, żywic... Szymona Syreńskiego ${ }^{9}$ (1613, Kraków, drukarnia Bazylego Skalskiego).

Wymienione zielniki ${ }^{10}$ omawiane są w nielicznych artykułach naukowych, w których zwykle bada się ich warstwę edytorską bądź wybrane tematy poruszane w herbariach. Do tej pory żadne z dzieł nie doczekało się wyczerpującego, całościowego opracowania ${ }^{11}$.

Warto podkreślić, że spośród trzech wymienionych wyżej tekstów, tylko dzieło Syreniusza można określić mianem „czystego” zielnika. Jest to również najobszerniejszy tekst tego typu (na 1584 kartach opisano 765 roślin). Traktat $O$ ziołach i mocy ich Falimirza stanowi zaledwie pierwszą część większego dzieła bez ustalonego tytułu (w pozostałych rozdziałach opisane zostały między innymi olejki, zwierzęta, ptaki, „nauka gwiazdeczna”). Także u Marcina z Urzędowa oprócz treści botanicznych podejmowana jest chociażby tematyka właściwości kruszców czy komplikacji porodowych.

9 Szymon Syreński, zw. Syreniuszem (1541-1611) - lekarz, botanik. Odbywał liczne podróże po Europie (m.in. Niemcy, Włochy), w trakcie których zwiedzał ogrody botaniczne. Po powrocie do kraju pracował jako lekarz we Lwowie. Wiadomości o ziołach czerpał zarówno z lektur, jak i z własnych obserwacji (Podole, Pokucie, Bieszczady, Babia Góra i in.). Jego zielnik opublikowany został po licznych perypetiach (związanych przede wszystkim z problemami finansowymi) dopiero dwa lata po śmierci autora (szczegółowo opisane [w:] R. Żurkowa, Wokót „Zielnika” Szymona Syreńskiego, „Rocznik Biblioteki Polskiej Akademii Nauk” 1985, r. 30, s. 9-11). Ufundowała go Anna Wazówna, publikacją zajął się następca Syreniusza, Gabriel Joannicy. Dzieło Syreniusza stanowiło ważne źródło wiedzy medycznej aż do XIX w. (G. Brzęk, Syreński (Syreniusz) Szymon, [w:] Słownik biologów polskich, red. S. Feliksiak, Warszawa 1987, s. 517).

10 Pomijam tu zielniki Hieronima Spiczyńskiego (1542) i Marcina Siennika (1568). Ich autorzy dokonywali niemalże wiernego przepisania tekstu Falimirza. W przypadku pokrzyku zmiany były zaledwie w obrębie pojedynczych słów, które nie rzutują na zawartość treściową hasła każdego herbarza. Ich dzieła wraz z O ziołach i mocy ich są zaliczane do cyklu „Unglerowskich ogrodów zdrowia" (od nazwiska wydawcy - Floriana Unglera). Ogrody zdrowia, czyli horti sanitatis przyjmowały początkowo formę encyklopedyczną. Wymieniano w nich rośliny w porządku alfabetycznym, wyjaśniano pokrótce ich zastosowanie w lecznictwie. Całość ilustrowano dość prymitywnymi drzeworytami. Inspirowano się w nich dziełami m.in. Dioskoridesa czy Pliniusza Starszego. Pierwsze tego typu dzieła powstawały w XV w. w Moguncji (K. Rostański, Szymon Syreniusz i jego dzieło, „Wiadomości Botaniczne” 1997, 41 (2), s. 7; M. Krzysztofik, Elementy astrologicznej koncepcji makro- i mikrokosmosu w traktacie Stefana Falimirza ,, O nauce gwiazdecznej”, „Terminus” 2015, t. 17, z. 1 (34), s. 91-92).

11 Najwięcej opracowań dotyczy ze zrozumiałych względów Stefana Falimirza (jako pioniera zielników w Polsce) i Szymona Syreńskiego zw. Syreniuszem (jego zielnik jest uznawany za ostatni i najdoskonalszy herbarz botaniczny). Tu prezentuję tylko wybrane teksty. Zielnikowi Falimirza w dużej części poświęcone zostały następujące opracowania: J. Rostafiński, Porównanie tak zwanych zielników Falimirza, Spiczyńskiego i Siennika, Kraków 1888 - warstwa edytorska, zakres $\rightarrow$ 
W O ziołach i mocy ich oraz w Herbarzu informacje o pokrzyku znaleźć można pod hasłem „Mandragora” (omawiana później jako „pokrzyk”). Tylko Syreniusz podaje od razu właściwą nazwę ziela, chociaż również wiąże roślinę z wyobrażeniami dotyczącymi legendarnej mandragory.

Do dziś nie jest jasno wythumaczona etymologia polskiej nazwy Atropa belladonna. Witold Doroszewski pojęcie ,pokrzyk” wiąże z „okrzykiem, zawołaniem, krzykiem, pokrzykiwaniem"12, co jednoznacznie kojarzy się z rzekomym wrzaskiem korzenia wyrywanej z ziemi mandragory. Natomiast Andrzej Bańkowski (w nawiązaniu do kształtu ziela) wywodzi to słowo od wyrazu „kierz”, czyli krzak ${ }^{13}$. W kontekście powiązań pokrzyku z mandragorą wart odnotowania jest fakt, iż ten pierwszy uprawiany był także w klasztorze benedyktyńskim przy Łysej Górze ${ }^{14}$. Tereny górzyste w wierzeniach ludu to miejsca tajemne, demoniczne. „Łyse” i „szklane” góry w bajkach i zabobonach były rodzajem ,antygór” - „wyznaczając pionowy ład, nakierowane były ku dołowi i otwierały drogę ku światu podziemnemu"15.

„Pokrzyk jest dwojaki - jeden samiec, drugi samica"16 - to od tej informacji zaczął swój wywód o roślinie Falimirz. Także Marcin z Urzędowa i Syreniusz wyodrębniają dwie „płcie” ziela. Zwykle różnią się one przede wszystkim budową - męskie miałyby być dorodniejszymi okazami. Inny jest

$\rightarrow$ treści; J. Szostak, Autorzy pierwszych zielników polskich - Stefan Falimirz, Hieronim Spiczyński i Marcin Siennik, „Archiwum Historii Medycyny” 1977, nr 40/3, s. 277-280 - poprawa błędów funkcjonujących dotychczas w świadomości badaczy nt. Falimirza i jego tekstu; L. A. Jankowiak, Szesnastowieczne stownictwo medyczne na przykładzie zielnika Stefana Falimirza „, O ziołach i mocy ich" z 1534 roku, [w:] Ad perpetuam rei memoriam. Profesorowi Wojciechowi Ryszardowi Rzepce z okazji 65. urodzin, red. J. Migdał, Poznań 2005, s. 151-158. Zob. też tejże, Stownictwo medyczne Stefana Falimirza, t. 1 (2005) - 2 (2006), Warszawa. Dzieło Syreniusza zostało opisane m.in. [w:] Rostański, dz. cyt., s. 7-12; Żurkowa, dz. cyt., s. 169-183. O tekście Marcina z Urzędowa w kontekście jego powiązań z ziemią sandomierską: A. Suchecka, T. Giergiel, Otwarcie sandomierskiego ogrodu Marcina z Urzędowa, „Wiadomości Botaniczne” 2015, nr 59 (3/4), s. 178-185.

12 W. Doroszewski, Stownik języka polskiego [przedruk elektroniczny], http://doroszewski. pwn.pl/haslo/pokrzyk (hasło: Pokrzyk) [dostęp: 2019-10-04.10.2019].

13 A. Bańkowski, Etymologiczny słownik języka polskiego, t. 2, Warszawa 2000, s. 68, [hasło: Pokrzyk].

14 A. Suchecka, dz. cyt., s. 85.

15 P. Kowalski, dz. cyt., s. 148.

16 S. Falimirz, $O$ ziołach $i$ mocy ich, drukarnia Floriana Unglera, starodruki Biblioteki Narodowej (Polona), sygn. SD XVI.Qu.7053, Kraków 1534, k. 87v. Wszystkie cytaty pochodzą $\mathrm{z}$ tego wydania. 
także kolor łodygi (ciemniejsza samicy i jaśniejsza samca) oraz rozmiar liści (większe u „mężczyzny”). Opis barw ich owoców wskazuje raczej na mandragorę niż pokrzyk, na przykład u Syreniusza żeńskie przypominają jarzębinę (poprzez kształt i barwę), męskie mają żółty kolor.

Omawiając właściwości lecznicze rośliny, wszyscy trzej autorzy najmniej uwagi poświęcają owocom. Falimirz kwestii medycznej przydatności pokrzykowych jagód w zasadzie nie rozwija, podając jednakże informację, iż „czynią [one] wielkie spanie"17. O ich właściwościach usypiających znaleźć można także informacje w Herbarzu i Zielniku...

Marcin z Urzędowa zaleca kobietom stosowanie nasion ziela jako środka przeczyszczającego: „Nasienie z tych jabłek purguje panie, zwłaszcza tajemne miejsca i miesiące wywodzi”18. Syreniusz z kolei uważa sok z owoców za dobre remedium na bóle głowy, gorączkę, cholerę. Radzi też go „pić obrażonym od bestyi jadowitych"19.

Liście uważane były za mniej wartościowe pod względem uzdrawiającym. Falimirz w jednym zdaniu uściśla wartość poszczególnych części rośliny: „Skóra korzenia tego najprzedniejsze lekarstwo jest, po tym owoc, a listy najpodlejsze"20.

Świeże, utarte liście Syreniusz proponuje przykładać do głowy i na wrzody - miały w ten sposób koić ból. Zasuszone, w postaci proszku, każdy autor radzi mieszać z innymi składnikami, które umożliwiają leczenie konkretnych dolegliwości. Na przykład Marcin z Urzędowa zaleca stosować liście zmieszane z mąką jęczmienną lub pszenną na ból stawów i wrzody.

Składniki posiłków popularne w domach, takie jak mleko, miód, sól, chleb czy mąka były często wykorzystywane jako środki lecznicze w medycynie ludowej. Placki z mąki spożywano na przykład w ramach walki z zapaleniem płuc ${ }^{21}$.

17 Tamże, k. 87r.

18 Marcin z Urzędowa, Herbarz polski, to jest o przyrodzeniu ziót i drzew rozmaitych, $i$ innych rzeczy do lekarstw należacych, Warszawa 2017 (reprint wydania: Kraków 1595), s. 202.

19 [Sz. Syreński], Zielnik herbarzem z języka łacińskiego zowią. To jest opisanie własne imion, kształtu, przyrodzenia, skutków i mocy ziót wszelakich..., spisane przez D. S. Syrenniusa, Warszawa 2013 (reprint wydania: Cracoviae 1613), s. 1377.

20 S. Falimirz, dz. cyt., k. 87v.

21 E. Łukuś, Medycyna ludowa, Nowy Sącz: Małopolskie Centrum Kultury SOKÓ£, http:// www.etnozagroda.pl/index.php/micms/doc/view/id/300 [dostęp: 21.09.2019]. 
Nie dziwi więc obecność tego składnika w pokrzykowych mieszankach. Mąka mogła także być stosowana jako środek neutralizujący trujące właściwości ziela. Przykład takiego jej użycia można znaleźć w Biblii:

Następnie podał ludziom do spożycia. Gdy tylko skosztowali polewki, krzyknęli: „Śmierć jest w kotle, mężu Boży!” i nie mogli jeść. On zaś powiedział: „Przynieście więc mąki!” I wsypał ją do kotła, mówiąc: „Rozlej ludziom i niech jedzą!” I już nie było nic trującego w kotle (2 $\mathrm{Krl} 4,40-41)$.

Niewątpliwie jednak to korzeń pokrzyku był najchętniej wykorzystywaną częścią rośliny, a jednocześnie, w świetle zielników, najbardziej niebezpieczną. Większość porad w każdym tekście dotyczy właśnie jego. Tworzy się z niego proszek, plastry, czopki, wyciska sok, będący składnikiem wielu wywarów. Wszyscy autorzy zgodnie zauważają groźbę zatrucia się rośliną i zalecają ostrożność przy jej zażywaniu:

[...] A gdyby tego soku [z korzenia - przyp. S. K.] więcej wziął niźlim powiedział: tedy umartwia abo umorzy ${ }^{22}$.

[...] ale trzeba mało brać, bo wiele biorąc - zabija ${ }^{23}$.

Pokrzykowego soku z pitym miodem tak wiele, coby trzecia część kwinty zaważył dać, gdzieby więcej, śmierci domieszcza ${ }^{24}$.

Najwięcej niepożądanych skutków spożywania pokrzyku lub picia wywarów, w których jest on głównym składnikiem, podaje Syreniusz. Wymienia wśród nich: zaburzenia myślenia i zachowania, nadmierną senność, szkodliwość samego zapachu owoców (ociężałość) oraz ich spożycia (śmierć). Ziele może trwale uszkodzić płód i doprowadzić do poronienia - „Płód z żywota też żywy wyrzuca" 25 . W świetle tekstów Falimirza i Marcina z Urzędowa Atropa belladonna nieraz wykorzystywana była zresztą jako naturalny środek poronny.

\footnotetext{
22 S. Falimirz, dz. cyt., k. 87r.

23 Marcin z Urzędowa, dz. cyt., s. 202.

24 Sz. Syreński, dz. cyt., s. 1375.

25 Tamże, s. 1377.
} 
Syreński przywołuje przypadek zatrucia kobiety owocami pokrzyku: „białogłowa zjadła pięć jagód pokrzykowych, za czym przyszła w zawrót głowy, także w mdłość serdeczną i w czerwieniałość ciała jako szkarłat”26. Podane objawy dobrze odzwierciedlają współczesny stan wiedzy na ten temat. Zatrucie rośliną może powodować suchość w ustach, gardle i krtani, spowolnienie oddechu, częstszy puls, zaczerwienienie skóry, zaburzenia widzenia i uczucie zamętu ${ }^{27}$. Korzeń pokrzyku mieszano z różnymi płynami (kobiecym mlekiem, winem lub miodem), co mogło mieć związek z chęcią zminimalizowania trujących właściwości ziela. Autorzy podają również przepis na pokrzykowe wino, wykorzystywane jako środek znieczulający (głównie przy amputacjach kończyn) i łagodzący ból.

Korzeń pokrzyku jest jednak interesujący nie tylko ze względu na wiele właściwości leczniczych, które mu przypisywano. To właśnie z nim wiązały się liczne wierzenia, łączące swojską roślinę z egzotyczną mandragorą. Im starszy zielnik, tym mniej w nim informacji na temat zabobonów dotyczących Atropa belladonna. Falimirz wspomina tylko o licznych oszustwach związanych z alrunikami. Przestrzega przed zakupem figurek, które nie dość, że drogie, są dodatkowo falsyfikatami, sporządzonymi z bardziej rozrośniętych i bulwiastych korzeni mieczyka lub kosaćca. W ich obrót zamieszane miały być wiedźmy, co dodatkowo zohydzało cały proceder:

A jako plotą, żeby był [korzeń - przyp. S. K.] na podobieństwo człowieka, toć jest kłam, a nigdy nieprawda. Matacze to z korzenia mieczykowego albo kosaćcowego uformują jakoby człowieka [...], a ludzi tym szalą dla pieniędzy, a wżdy niewiastom czarownym i babom z diabły się obierającym nieciężko dać za jeden który złoty, by go jedno mogła dostać, barzo rada każda ${ }^{28}$.

W przykładowym fragmencie zaznacza się równocześnie wielka niechęć autora wobec wszelkich przejawów praktyk czarnoksięskich. O pokątnym handlu magicznymi figurkami wspominają także pozostali autorzy zielników. Syreniusz dodaje, że w tego typu oszustwach wykorzystywano również korzenie przestępu

26 Tamże, s. 1377.

27 D. Frohne, dz. cyt., s. 96.

28 S. Falimirz, dz. cyt., k. 87v. 
i trzciny wodnej. Wprost przestrzegał on lud przed zakupem alruników, przedstawiając argumenty natury materialnej i religijnej: ,rozumiałem przestrzec prostaki, żeby się mataczom zwodzić nie dali, koszt ważąc niepotrzebny, a w szkodę i w grzech nie przychodzili" ${ }^{29}$. Wzmiankę o handlu zielem możemy znaleźć nie tylko w herbariach. W Dworzaninie polskim (1566) Łukasza Górnickiego jedna z przytaczanych anegdot dotyczy nieuczciwych kupców: „Podobne temu łotrostwo wyrządził drab jeden dobremu naszemu panu Jakubowi Borowskiemu, dworzaninowi, gdy mu przedał korzeń grzybieniowy miasto pokrzyku"30. Tutaj zamiast właściwego towaru sprzedano klientowi lilię wodną (grzybień).

Przywołane fragmenty świadczą o rozpowszechnieniu praktyk nabywania amuletów z pokrzyku. Uważano je za bardzo cenne. Ludzie przekazywali je sobie z pokolenia na pokolenie, otaczali wielką troską, a informację o ich posiadaniu zachowywali w ścisłej tajemnicy ze względu na wrogie nastawienie Kościoła wobec owych „talizmanów”, utożsamianych z działalnością czarownic i demonów ${ }^{31}$.

Cena alruników związana była z różnymi opowieściami, które podkreślały trudność zdobycia korzenia magicznej rośliny. Marcin z Urzędowa owe relacje traktuje jako wymysły. Dystansuje się wobec nich, wskazując niejasne źródła pochodzenia takich historii (,powiedają, że...”).

Pierwszą i najgroźniejszą przeszkodą do zdobycia cennego korzenia rośliny był w tradycji zabójczy krzyk ziela ${ }^{32}$. W Herbarzu autor przytacza przykład poradzenia sobie z tym problemem: ,jako gdy ten korzeń kopają, [...] a dlatego okopawszy psu u ogona, aby gdy krzyknie, wyrywając - pies zdechł, a nie człowiek”. I zaraz dodaje ,,ale to błazeństwo, ani temu żaden wierz”33. U Syreniusza można znaleźć wzmiankę o tym, że w tym celu wykorzystywano także koguta (koniecznie musiał mieć czarne umaszczenie). Zwierzęta były składane jako rodzaj ofiar dla demonicznej rośliny, która, „obłaskawiona” darem złożonego dla niej życia, umożliwiała wykorzystanie jej w magiczny sposób.

29 Sz. Syreniusz, dz. cyt., s. 1378.

30 Ł. Górnicki, Dworzanin polski, oprac. i wstęp R. Pollak, Warszawa 1950, s. 164-165.

31 P. Kowalski, dz. cyt., s. 307.

32 Zob. K. Szcześniak, Świat roślin światem ludzi na pograniczu wschodniej i zachodniej Słowiańszczyzny, Gdańsk 2008, s. 251.

33 Marcin z Urzędowa, dz. cyt., s. 201. 
Pies i kogut funkcjonowały w wyobraźni ludzi jako uosobienia nadprzyrodzonych mocy. Psy utożsamiano z wilkami, dlatego kojarzono je często $\mathrm{z}$ krwią i mordem oraz traktowano jako zwierzęta nieczyste. W wielu wierzeniach odgrywały rolę istot z pogranicza życia i śmierci oraz materii i duchowości. Czarnym osobnikom dodatkowo przypisywano funkcję omenu zwiastującego nieszczęście. Tak jak pies symbolizował mrok, tak koguty wiązano ze sferą solarną i życiem. W mitologiach bywały strażnikami domów (odganiały demony - wizerunek ptaka nieraz zyskiwał w wyobrażeniach moc talizmanu), ucieleśniały płodność, przynosiły szczęście nowożeńcom. Wyjątkiem były czarne samce. W wierzeniach ludowych potrafiły one znieść jajo, z którego wylęgał się bazyliszek. Po przeżyciu dwunastu lat ptak zmieniał się w diabła. Gotowanie na rozstajnych drogach koguta o czarnym upierzeniu umożliwiało przyzwanie demona ${ }^{34}$.

Jak widać, ofiary poświęcone mandragorze jednoznacznie kojarzyły się z czarną magią, co z pewnością zmniejszało wyrzuty sumienia związane z zabijaniem tych właśnie zwierząt i odpowiadało złowrogim właściwościom mandragory.

Lękiem napawały ludzi miejsca, w których, według ludowych przekazów, pokrzyk występuje. Syreniusz pisał:

$\mathrm{Na}$ jakich miejscach i z czego rosną: to jest pod szubienicami, gdzie z moczu tych, które wieszą, rosną [...]. Te i inne baśni o pokrzyku tych mataczy i oszustów bywają, które są wzięte z Józefa Żydowina z ksiąg 7. z rozdziału 25. o zburzeniu Jerozolimskim ${ }^{35}$.

Szubienice należą do sfery nieczystej śmierci. Wiążą się z wykonywaniem kary za ciężkie przewinienia. Nasuwają również skojarzenia z zakazanym w wielu religiach samobójstwem. Przebywanie w pobliżu szubienic i groźba zgonu związana ze zdobyciem rośliny zmuszały do zmierzenia się z lękiem przed śmiercią. Pokonanie własnych psychicznych ograniczeń umożliwiało

34 P. Kowalski, dz. cyt., s. 446-448; 220-223.

35 Sz. Syreński, dz. cyt., s. 1378. Prawdopodobnie botanik przywołuje tu dzieło Józefa Flawiusza. Zob. XVI-wieczne tegoż autora Historia Józefa syna Gorionowego o wojnie żydowskiej na dwie części rodzielona. [...] przy tym przydana jest chorografia, to jest opisanie ziemie świętej [...], thum. A. Rymsza, Wilno 1595. 
zdobycie nie tylko cennego lekarstwa, amuletu czy skarbu, ale również miłości. Na dawnych rycinach, jak na przykład na XVII-wiecznej Mandragorze Abrahama Bosse'a, roślina symbolizowała często dwoistość natury kobiety. Była też powszechnie traktowana jako ziele sprzyjające płodności (warto podkreślić, że w omawianych zielnikach kłącze pokrzyku opisywano jednak przede wszystkim jako środek poronny i wywołujący impotencję) ${ }^{36}$.

Skojarzenie mandragory $\mathrm{z}$ ważnym środkiem pomocnym w budowaniu miłosnej intrygi pojawia się już w Biblii. Ziele odgrywa rolę karty przetargowej w rywalizacji dwóch sióstr, Lei i Racheli, o względy Jakuba i zapewnienie mu dostatecznej liczby potomstwa (Rdz 30, 14-16). Sam korzeń przywodzi na myśl kształty falliczne i przez to symbolizujące erotykę. Widać to na przykładzie sielanki XVII-wiecznego twórcy - Jana Gawińskiego, w której opisano rytuał zadawania impotencji mężczyźnie:

Wmocz korzeń w tej tu zimnej wodzie,

Po tym go złam, a mów tak: „Jak ten korzeń w chłodzie,

Tak on, niechaj oziębnie, niechaj nic nie sprawi

Półmartwy, aż się nazad do swej pani stawi!37

Zauważalne jest, że w przekazach o leczniczych właściwościach rośliny szczególnie istotną rolę odgrywa korzeń, który pod różnymi postaciami (soku, czopków, plastrów) służył głównie do kojenia bólu oraz przeczyszczania organizmu z wszelkich toksyn. Każdy autor ostrzegał przed nadmiernym dawkowaniem ziela z uwagi na poważne skutki uboczne. Warto przy tym podkreślić, że chociaż XVI- i XVII-wieczne zielniki straciły obecnie pełnię swej wiarygodności, ich autorzy, wykorzystując dorobek poprzedników, podali wiele informacji, które również dzisiaj można odnaleźć w kompendiach poświęconych leczniczym właściwościom roślin (na przykład odnośnie dobroczynnego wpływu zawartej w pokrzyku atropiny na gałki oczne - substancja ta do dziś

36 H. Dziechcińska, Kobieta w życiu i literaturze XVI i XVII wieku, Warszawa 2001, s. 17.

37 J. Gawiński, Odczary na Simonidesowe „Czary”, [w:] tegoż, Sielanki z gajem zielonym, oprac. E. Rot, Warszawa 2007, s. 54. 
wykorzystywana jest w okulistyce; ponadto wiarygodnie opisywali objawy przedawkowania ziela).

Kłącza rośliny pełniły prymarną funkcję również w magii. To właśnie $\mathrm{w}$ warstwie wierzeń i samym nazewnictwie uobecnia się silne powiązanie rodzimego pokrzyku z mandragorą. Mimo różnic w budowie morfologicznej, podobne skutki działania sprzyjały utożsamieniu obydwu gatunków. Stąd wynika przekonanie o zabójczym krzyku korzenia pokrzyku, mocy amuletów i niezwykłych miejscach występowania ziela. Autorzy zielników z dystansem odnosili się do wiary w nadnaturalne moce owej rośliny. Podkreślali, że tylko przekazują zasłyszane historie, nieraz wprost zastrzegali, że sami nie dają im wiary. Jednocześnie zapewniali, że to głównie płeć żeńska zainteresowana była zakupem quasi-magicznych bulw. Falimirz przekonuje, że interesowały się nim „baby” praktykujące magię. Panowała wówczas wiara w to, że ziele wchodziło w skład maści czarownic, umożliwiającej im odbywanie lotu na sabaty. Miało również umożliwiać rozwój zdolności profetycznych czarownic ${ }^{38}$. Marcin z Urzędowa sugeruje, że to kobieta bardziej podatna była na wiarę w przesądy związane z rośliną: „Dziwne błazeństwa u polskich głupich niewiast około pokrzyku [...]"39. Wiązało się to zapewne z przekonaniem o większej słabości intelektualno-emocjonalnej płci żeńskiej w porównaniu do mężczyzn oraz narastającą liczbą procesów o czary w tym czasie.

Dawniej mandragorę chciano widzieć nie tylko w pokrzyku, ale też lulecznicy kraińskiej (brunatnej) czy szaleju pospolitym ${ }^{40}$. O tym ostatnim jako kolejnym odpowiedniku egzotycznego ziela wspominają zresztą Falimirz i Syreniusz ${ }^{41}$. Udowadnia to, jak ważną częścią polskiej duchowości i medycyny stała się mandragora, co zachęca do jeszcze bardziej pogłębionych badań nad jej fenomenem w naszej kulturze i literaturze.

38 K. Szcześniak, dz. cyt., s. 250-251.

39 Marcin z Urzędowa, dz. cyt., s. 201.

40 B. Gustawicz, O korzeniach czarodziejskich $w$ lecznictwie ludowem u nas $i$ gdzie indziej, „Lud” 1904, t. 10, s. 276-277.

41 Syreniusz wymienia też płomyk jako roślinę, której także częściowo przypisywano cechy mandragory, zob. tegoż, dz. cyt., s. 335-336. 


\section{Bibliografia}

Bańkowski A., Etymologiczny słownik języka polskiego, t. II. Warszawa 2000.

Biblia Tysiąclecia. Pismo Święte Starego i Nowego Testamentu, Poznań 2003, http:// biblia.deon.pl/index.php.

Brzęk G., Syreński (Syreniusz) Szymon, [w:] Słownik biologów polskich, red. S. Feliksiak, Warszawa 1987.

Brzozowski S., Falimirz Stefan, [w:] Słownik biologów polskich, red. S. Feliksiak, Warszawa 1987.

Doroszewski W., Słownik języka polskiego [przedruk elektroniczny], http://doroszewski.pwn.pl/haslo/pokrzyk/, Warszawa 2000.

Dziechcińska H., Kobieta w życiu i literaturze XVI i XVII wieku, Warszawa 2001.

Falimirz S., O ziołach i mocy ich, drukarnia Floriana Unglera, starodruki Biblioteki Narodowej (POLONA), sygn. SD XVI.Qu.7053, Kraków 1534.

Flawiusz T., Historia Józefa syna Gorionowego o wojnie żydowskiej na dwie części rodzielona. [...] przy tym przydana jest chorografia, to jest opisanie ziemie świętej [...], tłum. A. Rymsza, drukarnia Jana Kancara, starodruki Biblioteki Narodowej (POLONA), sygn. SD XVI.0.387,, Wilno 1595.

Frohne D., Leksykon roślin leczniczych (red. wyd. I polskiego A. Noculak-Palczewska), Wrocław 2010.

Gawiński J., Odczary na Simonidesowe "Czary”, [w:] tegoż, Sielanki z gajem zielonym, (oprac. E. Rot), Warszawa 2007.

Górnicki Ł., Dworzanin polski (oprac. i wstęp R. Pollak), Warszawa 1950.

Gustawicz B., O korzeniach czarodziejskich w lecznictwie ludowem u nas i gdzie indziej, "Lud" 1904, t. 10, s. 276-277,

Hajdukiewicz L., Marcin z Urzędowa, [w:] Internetowy Polski Słownik Biograficzny, https://www.ipsb.nina.gov.pl/a/biografia/marcin-z-urzedowa?print.

Jankowiak L. A., Słownictwo medyczne Stefana Falimirza, t. 1-2, Warszawa 20052006.

Jankowiak L. A., Szesnastowieczne słownictwo medyczne na przykładzie zielnika Stefana Falimirza „O ziołach i mocy ich" z 1534 roku, [w:] Ad perpetuam rei memoriam. Profesorowi Wojciechowi Ryszardowi Rzepce z okazji 65. Urodzin, red. J. Migdał, Poznań 2005.

Kopaliński W., Słownik symboli, Warszawa 2001.

Kowalski P., Kultura magiczna. Omen, przesąd, znaczenie, Warszawa 2007. 
Krzysztofik M., Elementy astrologicznej koncepcji makro- i mikrokosmosu w traktacie Stefana Falimirza „O nauce gwiazdecznej”, „Terminus” 2015, t. 17, z. 1 (34), S. 89-112.

Kuźnicka B., Znaczenie roślin halucynogennych w polskich tradycjach kulturowych: zarys problematyki, „Analecta. Studia i Materiały z Dziejów Nauki” 1992, 1/1, s. 113-116.

Marcin z Urzędowa, Herbarz polski, to jest o przyrodzeniu ziół i drzew rozmaitych, drukarnia Łazarzowa - Łazarz Andrysowicz, Kraków 1595 [na podstawie reprintu oryginału, wyd. Gra_fika, Warszawa 2013)..

Podbielskowski Z., Sudnik-Wójcikowska B., Słownik roślin użytkowych polski, łaciński, angielski, francuski, niemiecki, rosyjski, Warszawa 2003.

Rostafiński J., Porównanie tak zwanych zielników Falimirza, Spiczyńskiego i Siennika, Kraków 1888.

Rostański K., Szymon Syreniusz i jego dzieło, „Wiadomości Botaniczne” 1997, 41(2), s. 7-12.

Suchecka A., Sandomierski ogród Marcina z Urzędowa, "Głos Ziemi Urzędowskiej” 2015, s. 81-90, http://gokurzedow.pl/u/gzu15/7.pdf.

Suchecka A., Giergiel T., Otwarcie sandomierskiego ogrodu Marcina z Urzędowa, „Wiadomości Botaniczne” 2015, nr 59 (3/4), s. 178-185.

Syreński Sz., Zielnik herbarzem z łacińskiego zowią. To jest opisanie własne imion, kształtu, przyrodzenia, skutków i mocy ziół wszelakich drzew, krzewin i korzenia ich, kwiatu, owoców, soków, miazg, żywic..., 1613, Kraków, drukarnia Bazylego Skalskiego [na podstawie reprintu oryginału, wyd. Graf ika, Warszawa 2013).

Szcześniak K., Świat roślin światem ludzi na pograniczu wschodniej i zachodniej Słowiańszczyzny, Gdańsk 2008.

Szostak J., Autorzy pierwszych zielników polskich - Stefan Falimirz, Hieronim Spiczyński i Marcin Siennik, „Archiwum Historii Medycyny” 1977, nr 40/3, s. 277-280.

Szostak J., Farmakognozja, farmacja galenowa $i$ aptekarstwo $w$ renesansowych zielnikach polskich, Warszawa 2006.

Zemankowie A. i B., Roślina i "sacrum” w historii cywilizacji, [w:] Geografia i sacrum, red. Domański B., Skiba S., t. 2, Kraków 2005, s. 471-477.

Żurkowa R., Wokół „Zielnika” Szymona Syreńskiego, „Rocznik Biblioteki Polskiej Akademii Nauk" 1885, R. 30, s. 9-11. 